\title{
FUNCTIONS OF IRONICAL MODE IN THE RUSSIAN TRAVELOGUE
}

\author{
Ekaterina A. Shcheglova \\ Saint Petersburg State University, Saint Petersburg, Russia
}

\begin{abstract}
The research is performed within the linguistic stylistic approach which allows to determine the pragmatic foundation as existence of the ironic mode. The article is devoted to consideration of travelogue as a special type of text and to the evidence that irony is one of the universal features of travelogue as a text, which helps to define the borders between "own" and "other" and is aimed at perception of these borders. The material for analysis includes the texts of the $19^{\text {th }}$ and $20^{\text {th }}$ centuries, which vividly express the author's ironic attitude towards the reality. The functions of ironic mode in the Russian travelogue are revealed. The dominating role of the educating function is demonstrated. It is determined that ironic mode is characterized by polyfunctionality simultaneous actualization of several functions, including: motivational (the motivation of readers to follow the author's travel as well as accept his ideas), expressive and contact-setting (as combination of contact initiation and harmonization of communication), aesthetic (making an object of description artistic and sensitive) functions. The research might continue with studying the ironic mode in travelogue of different times in a comparative aspect as well as analyzing the ironic mode within the peculiarities of the author's individual style. function

Key words: travelogue, ironic mode, polyfunctionality, pragmatics, functions of ironic mode, educational

Citation. Shcheglova E.A. Functions of Ironical Mode in the Russian Travelogue. Vestnik Volgogradskogo gosudarstvennogo universiteta. Seriya 2. Yazykoznanie [Science Journal of Volgograd State University. Linguistics], 2020, vol. 19, no. 6, pp. 157-168. (in Russian). DOI: https://doi.org/10.15688/jvolsu2.2020.6.12

\section{ФУНКЦИИ ИРОНИЧЕСКОЙ ТОНАЛЬНОСТИ В РУССКОМ ТРАВЕЛОГЕ}

\author{
Екатерина Александровна Щеглова \\ Санкт-Петербургский государственный университет, г. Санкт-Петербург, Россия
}

\begin{abstract}
Аннотация. Исследование проведено в русле лингвостилистического подхода, который позволяет установить прагматические основы существования иронической тональности. Статья посвящена рассмотрению травелога как особого типа текста и доказательству положения о том, что ирония составляет одну из характерных универсальных черт травелога как текста, определяющего границы «своего» и «чужого» и направленного на познание этих границ. Материалом для анализа послужили тексты XIX и XX вв., в которых ярко выражено авторское ироническое отношение к действительности. Выявлены функции иронической тональности в русском травелоге. Показана доминирующая роль просветительской функции. Охарактеризована специфика побудительной (побуждение читателя к повторению путешествия автора, а также к принятию его идей), экспрессивной, контактоустанавливающей (совмещающая как установление контакта, так и установку на гармонизацию общения), эстетической (эстетизация объекта описания) функций. Установлено, что иронической тональности свойственна полифункциональность - одновременная актуализация нескольких функций. В качестве продолжения исследования определено изучение иронической тональности в травелогах разного времени в сопоставительном аспекте, а также анализ функционирования иронической тональности в свете особенностей индивидуального стиля автора.
\end{abstract}

Ключевые слова: травелог, ироническая тональность, полифункциональность, прагматика, функции иронической тональности, просветительская функция. 
Цитирование. Щеглова Е. А. Функции иронической тональности в русском травелоге // Вестник Волгоградского государственного университета. Серия 2, Языкознание. - 2020. - Т. 19, № 6. - С. 157-168. - DOI: https://doi.org/10.15688/jvolsu2.2020.6.12

\section{Введение}

Термин «травелог» обычно обозначает совокупность текстов, в которых описываются реальные путешествия, совершенные их авторами (а иногда и нереальные; о соотношении вымысла и реальности в путевой литературе см.: [Шёнле, 2004]). Несмотря на типологическую и историческую разнородность таких текстов (хождения, путевые очерки, литературные путешествия, современные трэвел-медиатексты и т. п.), их объединяет объект описания (другая реальность - «другая страна» [Редькина, 2011], «иная» действительность [Кочетова, Плавина, 2018]), актуализация бинарной оппозиции «свое - чужое», особое положение автора как фигуры, обеспечивающей единство концептуального осмысления действительности, доминантная интенция (осведомление о территории [Дускаева, 2014]) и т. п. Это позволяет исследователям характеризовать травелог как дискурсивный жанр (см., например: [Плавина, 2019]).

Травелог активно изучается в разных аспектах в различных научных традициях, однако ироническая тональность как одна из его характерных черт, присущая целому кругу ключевых текстов русского травелога XIX и XX вв. (путешествия И.А. Гончарова, В.В. Маяковского, С.А. Есенина, И. Ильфа, Е. Петрова и др.), объектом исследования не становилась.

В лингвистике термин «тональность» не имеет однозначной научной интерпретации (см., например: [Ильинова, Цинкерман, 2019; Карасик, 2008; Тупикова 2011; 2017; и др.]). В рамках настоящего исследования мы опираемся на классическую дефиницию, данную Т.В. Матвеевой, которая определяет тональность как текстовую категорию, «в которой находит отражение эмоционально-волевая установка автора текста при достижении конкретной коммуникативной цели, психологическая позиция автора по отношению к излагаемому, а также к адресату и ситуации общения» [Матвеева, 2003, с. 549]. В таком понимании отражена непосредственная связь то- нальности с эксплицированием авторской субъективации в тексте, проявляющейся на всех языковых уровнях - фонетическом, лексическом, морфологическом и синтаксическом. Представляется, что ироническая тональность занимает особое место в травелоге. Это предположение имеет несколько оснований (кроме уже упоминаемой частотности реализации).

Во-первых, ироническая тональность базируется на скрытом комизме, вызванном неожиданным сопоставлением, нарушением логических связей [Тупикова, 2017, с. 405], то есть в ее основе лежит противоречие мыслительной природы. Путешествие всегда является ситуацией «слома культур» [Лотман, Успенский, 1987; Пономарёв, 2011]: привычное приходит в столкновение с «другим», непривычным, находящимся вне пределов устоявшейся нормы, на фоне чего путешественником (и читателем путешествия) осуществляется поиск себя в мире [Leed, 1978; Blanton, 1997]. Таким образом, в травелоге это противоречие обусловлено самим объектом описания.

Во-вторых, в травелоге продуктивность иронической тональности определена коммуникативной целью: описанием «другой» действительности, которая воспринимается как нарушение нормы. Важно при этом, что «имеется в виду не всякое отклонение от нормы, а лишь такое, что вызывает возникновение добавочного смысла» [Трач, 2007, с. 176]. В травелоге приращение этого добавочного смысла становится необходимым шагом к познанию мира и себя в этом мире. Путешествие (и реальное, и воплощенное в слове) имеет воспитательный и просветительский потенциал: так видели это сами путешественники, так осмысляется путешествие как феномен в науке (с философских позиций [Беккер, 2011]; в историко-культурном ключе [Козлов, 2003; Стефко, 2009]. Проведенное Д. Чандлером исследование таких феноменов, как ирония, метафора, метонимия, синекдоха, показало, что они образуют систему когнитивных инструментов, с помощью которых происходит ка- 
тегоризация явлений окружающей действительности [Chandler, 2007]. А.Ф. Лосев подчеркивал, что отражение истины составляет сущностное свойство иронии [Лосев, 1966]. Эту же мысль на материале текстов просветительской журналистики XVIII в. подтверждает А.А. Малышев [Малышев, 2015; 2016].

В-третьих, особое положение иронической тональности в травелоге обусловлено характером взаимоотношения коммуницирующих субъектов. Традиционно исследователями травелога отмечается специфика автора в текстах такого типа, их наполненность авторским присутствием: авторским «я» определяется маршрут и локации, точка наблюдения и т. п. И.К. Архипов, рассуждая о комическом, замечает: «Мир вокруг нас сам по себе ни серьезен, ни важен, ни смешон, ни трагичен, он - никакой с эмоциональной точки зрения; ее привносит только сам человек под диктовку своих внутренних потребностей, которые он сам же себе устанавливает» [Aрхипов, 2007, с. 116]. Автор травелога должен не просто показать читателю мир как он есть, читатель ждет от него оценки описываемых объектов («субъективная достоверность» [Щеглова, 2013]). Ирония же является не только приемом, но типом восприятия мира, основанным, как показано лингвистами, на критическом отношении к действительности и интеллектуальном усилии [Медиалингвистика..., 2018, с. 252]. Ироническая тональность делает описываемую действительность интереснее для читателя и становится средством актуализации семантических доминант повествования. При этом следует учитывать, что травелог всегда находится в тесном взаимодействии с действительностью, отражая ее, реагируя на ее изменения, отвечая на потребности читателя в каждый отдельно взятый временной промежуток (о значении фигуры автора в путешествии и взаимодействии путевого текста с действительностью см.: [Шадрина, 2003; Шачкова, 2008]). С этой точки зрения ироническая тональность в травелоге соответствует общей идеологической ориентации общества определенного времени, а автор выступает как проводник ключевых идей своего времени.

Рассуждая о прагматике иронии в языке, Б.А. Гомлешко пишет: «Прагматичность иронии в тексте определяется тем, что иронический акт является актом оценивания, а оценка стоит в преддверии выбора и решения, влекущих за собой переход к практическим действиям» [Гомлешко, 2008, с. 11]. Исследователь приводит список функций иронии, однако очевидно, что он должен меняться и подвергаться корректировке в зависимости от типа текста. В статье представлены результаты такой корректировки применительно к жанру травелога.

\section{Материал и методы}

Материалом послужили тексты XIX и $\mathrm{XX}$ вв., написанные на основании реально совершенных путешествий, в которых ироническая тональность играет ключевую роль в текстоформировании. В данном случае мы сознательно отказываемся от рассмотрения взятых для анализа текстов в рамках историко-литературной традиции, поскольку нас интересует исключительно прагматика использования иронической тональности как лингвистического феномена. При этом ироническая тональность понимается как своего рода универсалия, характерная для целого ряда травелогов разного времени, обладающая неизменным набором функциональнопрагматических характеристик. Мы не включаем в эмпирический материал тексты XXI в. (они использованы лишь на уровне фрагментарного сопоставления), поскольку в них наблюдается принципиально иная прагматика обращения к иронической тональности.

Исследование проведено в русле лингвостилистического подхода к анализу текстов, который позволяет установить прагматические основы существования иронической тональности как полифункционального явления. Функции иронической тональности определяются на основе анализа контекстов, в которых она проявляется, выделяются языковые средства разных уровней, участвующие в ее создании.

\section{Результаты и обсуждение}

\section{Просветительская функция}

В качестве основной функции иронической тональности была выделена просветительская, 


\section{МАТЕРИАЛЫ И СООБЩЕНИЯ}

поскольку сам по себе рассказ о перемещении в иную реальность предполагает передачу автором нового знания своему читателю. Ироническая тональность является инструментом травелога, позволяющим декодировать новые знания, что демонстрирует следующий пример из очерков путешествия И.А. Гончарова «Фрегат “Паллада"»:

Вот теперь у меня в комнате лежит доха, волчье пальто, горностаевая шапка, беличий тулуп, заячье одеяло, торбасы, пыжиковые чулки, песцовые рукавицы и несколько медвежьих шкур для подстилки. Когда станешь надевать все это, так чувствуешь, как постепенно приобретаешь понемногу чего-то беличьего, заячьего, оленьего, козлового и медвежьего, а человеческое мало-помалу пропадает. Кухлянка и доха лишают употребления воли и предоставляют полную возможность только лежать. В пыжиковых чулках и торбасах ног вместе сдвинуть нельзя, а когда наденешь двойную меховую шапку, или, по-здешнему, малахай, то мысли начинают вязаться ленивее в голове и одна за другою гаснут. Еще бы что-нибудь прибавить, так, кажется, над вами того и гляди совершится какая-нибудь любопытная метаморфоза (Гончаров, с. 676).

Автор использует маску неопытного путешественника, для которого в новинку все трудности странствий, причем не оставляет ее и при повествовании о завершении путешествия - возвращении через Сибирь (о сочетании черт путешественника и домоседа в образе автора см.: [Строганов, 2002]). Она помогает автору через описание непосредственного эмпирического опыта рассказать читателю о деталях окружающей действительности, приблизить их к нему (ср. прием остранения по В.Б. Шкловскому). Эффект присутствия создается в приведенном отрывке комплексом языковых средств: настоящее повествовательное время, определенно-личные предложения со сказуемыми, выраженными глаголом в форме 2 л., личное местоимение вbl. Все это усиливает ироническое звучание контекста, дает возможность читателю «примерить» ситуацию на себя, узнать, как можно себя почувствовать, надев все эти предметы одежды. Чуть ранее из диалога автора с местными жителями читатель узнает значение таких малоизвестных для жителя европейской части России слов, как торбасы, пыжиковый, доха, кухлянка. Ирония в этом случае становится механизмом обработки нового знания, инструментом его закрепления, осмысления новых фактов действительности.

Подобным образом в качестве инструмента просвещения ироническая тональность проявляет себя во многих текстах, относящихся к травелогу, например:

К ужину давали незнакомые мне еды - зеленый кокосовый орех с намазывающейся маслом сердцевиной и фрукт манго - шарж на банан, с большой волосатой косточкой (Маяковский, с. 271).

Иронию создает неузуальное употребление слова $е д a$ во множественном числе, а также «неузуальное» уподобление манго банану, при этом метафора шарж на банан демонстрирует осознаваемую автором лишь частичную состоятельность такого уподобления.

Путешественник в описании своего странствия вынужден так или иначе обращаться к деталям быта, которые сами по себе не вызывают интереса читателя. Ироническая тональность позволяет нетривиально информировать о вещах очевидных или банальных. Это свойство иронической тональности часто актуализируется в тех случаях, когда речь идет о территории, уже известной читателю. Например, М.Л. Михайлов в «Лондонских заметках» прибегает к иронии, описывая комнату в английской гостинице, устройство которой было хорошо известно образованным читателям того времени:

Главное место занимает монументальных размеров кровать, которая в Германии могла бы прослыть за четыре постели - по десять грошей каждая... Кроме того, в комнате, разумеется, есть умывальный стол, комод и туалет с зеркалом; но больше уж ничего не требуйте! Кресло к камину есть уже роскошь. Вы можете посидеть перед огнем и на стуле, если зажигаете огонь вечером. Столика к постели тоже не спрашивайте. Как необтесанный foreigner, вы усвоили себе вредную привычку читать на сон грядущий: отвыкайте от нее в стране здоровья и комфорта. Притом к монументальной постели, данной вам, и стол нужен монументальный; он только лишнее место займет. Не вздумайте также расположиться писать в нумере. Разве вы отличаетесь способностью превращать в письменный стол доску над камином и возите с собой чернильницу, песочницу и прочие так называемые канцелярские припасы... Ну тогда другое дело!.. (Михайлов, с. 327 ). 
Фрагмент насыщен существительными, обозначающими предметы быта. Ироническая тональность позволяет читателю осознать различия между привычным видом перечисленных в описании вещей и тем, как их увидел автор, который мастерски играет с читательской пресуппозицией: неслучайно в данном фрагменте появляется сочетание страна здоровья и комфорта, отражающее стереотипное восприятие Англии в России XIX в. (см. многочисленные описания Туманного Альбиона в литературных произведениях середины и второй половины XIX в.).

Сходным образом используется ироническая тональность при описании путешествий по своей стране, например, в следующем фрагменте из путевых заметок Г.И. Успенского (очерк «Пока что»), содержащем описание игры типичного провинциального оркестра в одном из волжских городков:

Но вот на берегу, на бульваре, послышались звуки музыки: скрипки, флейты и кларнеты давали о себе знать отрывочными визгливыми звуками, напоминавшими вопли испуганных и находящихся в каком-то переполохе кур, - но какая-то труба заявляла о себе чрезвычайно решительно и твердо. Короткими, толстыми и тяжелыми, как хорошие березовые дрова, звуками кидала она в средину воплей раскудахтавшихся кларнетов и флейт, всякий раз совершенно без малейшего, так сказать, остатка, заглушая всю суматоху и все неистовое кудахтание в музыкальном курятнике (Успенский, с. 116).

В приведенном контексте значимым оказывается момент узнавания и «переоткрытия» читателем хорошо знакомого ему предмета описания, обычно относящегося к сфере повседневности.

\section{Побудительная функция}

Автор может иметь намерение склонить читателя к своей точке зрения, как это происходит в «Железном Миргороде» С.А. Есенина:

Сила железобетона, громада зданий стеснили мозг американца и сузили его зрение. Нравы американцев напоминают незабвенной гоголевской памяти нравы Ивана Ивановича и Ивана Никифоровича. Как у последних не было города лучше Полтавы, так и у первых нет лучше и культурней страны, чем Америка (Есенин, с. 172).
Это фрагмент из заключительной части очерка, в которой соединяются все сильные смысловые позиции текста: железобетонные конструкции как рефренный элемент описания Америки на протяжении всего очерка, аллюзия к сборнику повестей Н.В. Гоголя «Миргород», создающая второй смысловой план и коррелирующая с заголовком. К аллюзии на текст «Миргорода» автор прибегает неоднократно, улавливая внешнее сходство между увиденной им Америкой и созданной Н.В. Гоголем реальностью. В приведенном же фрагменте эксплицируется внутреннее сходство. Все речевые средства должны убедить читателя в правомерности вынесенной автором оценки.

Ироническая тональность может выражать побуждение к действию, например повторить путешествие автора или хотя бы допустить для себя возможность такого повторения. Так, у А.В. Вышеславцева находим следующее рассуждение, призванное, казалось бы, уничтожить в читателе само желание путешествовать:

Как Средиземное море сделалось внутренним озером, и прежде живые его колонии: Тир, Карфаген, Венеция и т. д., развалинами своими оживляют берега его, так Атлантический океан стал Средиземным морем, тоже с своими Геркулесовыми столбами, - с мысом Горном и мысом Доброй Надежды, - за пределы которых манит теперь еще более обширное море... Из этого вы можете заключить, что переход наш от Шербурга до мыса Доброй Надежды никак не может назваться путешествием. Мы просто ехали, как ехал Василий Иванович из Москвы в Мордасы; ехали тоже по беспокойной дороге и также заезжали на станции, из которых первая была остров Мадера, другая - Тенериф, третья - Сан-Яго и четвертая - остров Вознесения (Вышеславцев, с. 5-6).

Ироническое звучание данному отрывку придает сравнение остановок при совершении кругосветного путешествия с обычными остановками на почтовых станциях при поездке по России. Из Москвы в Мордасы совершали путешествие герои повести В.А. Соллогуба «Тарантас» - Иван Васильевич, считающий эту поездку путешествием, и Василий Иванович, утверждающий обратное. Напомним, что юному романтику Ивану Васильевичу хватило четырех дней для того, что- 


\section{МАТЕРИАЛЫ И СООБЩЕНИЯ}

бы убедиться в невозможности путешествия в России. Повесть широко обсуждалась после своего выхода в 1840 г. (см., в частности ее критический разбор, принадлежащий В.Г. Белинскому). Между тем для большинства русских читателей перечисленные топонимы являлись экзотическими, а описание совершенного автором путешествия представляло безусловный интерес. Дальнейшее наполненное красками повествование о путешествии через Атлантический океан подтверждает, что смысл данного фрагмента противоположен прямому пониманию сказанного, а ироническая тональность призвана убедить читателя в том, что путешествие до мыса Доброй Надежды вполне безопасно, а маршрут освоен, в то время как далекие морские путешествия в России XIX в. считались проявлением авантюрной натуры (см. схожее рассуждение в произведении «Фрегат “Паллада”» И.А. Гончарова).

Еще одним аспектом реализации данной функции в травелоге XX в. стало использование иронической тональности как инструмента передачи идеологической установки автора:

Первый класс тошнит куда хочет, второй - на третий, а третий - сам на себя (Маяковский, с. 267).

\section{Экспрессивная функция}

Поскольку тексты, относящиеся к травелогу, всегда отражают субъективность авторского восприятия действительности (исключительно глазами автора видит читатель другую страну, которая является предметом описания), то экспрессивная функция иронической тональности становится одной из важнейших. Единство авторского эмоционального восприятия - одно из текстообразующих начал травелога. В качестве иллюстрации приведем пример из путевых очерков И.А. Гончарова, в котором авторская экспрессия связана с опытом использования крутящегося стула:

Я кое-как вскарабкался на антигеморроидальное седалище, и г-н Каннингам тоже; мы с высот свободно обозревали друг друга. «На чем вы приехали?» - спросил меня г-н Каннингам. Я только было собрался отвечать, но пошевелил нечаянно ногой: круглое седалище, с винтом, повернулось, как по маслу, подо мной, и я очутился лицом к стене. «На шкуне», - отвечал я в стену и в то же время с досадой подумал: «Чье это, английское или американское удобство?» - и ногами опять приводил себя в прежнее положение (Гончаров, с. 415).

\section{Контактоустанавливающая функция}

Прагматика использования иронической тональности с целью контактоустановления в травелоге зависит от авторских намерений и установок аудитории, к которой обращен текст. Контактоустановление может быть непосредственным образом сопряжено с реализацией просветительской функции, становясь необходимым условием трансляции нового знания. Часто в этом случае происходит игра с пресуппозицией читателя, иногда совпадающей с пресуппозицией автора. Так, в начале своего путешествия И.А. Гончаров замечает:

Я думал, судя по прежним слухам, что слово «чай» у моряков есть только аллегория, под которою надо разуметь пунш, и ожидал, что когда офицеры соберутся к столу, то начнется авральная работа за пуншем, загорится живой разговор, а с ним и носы, потом кончится дело объяснениями в дружбе, даже объятиями, - словом, исполнится вся программа оргии. Я уже придумал, как мне отделаться от участия в ней. Но, к удивлению и удовольствию моему, на длинном столе стоял всего один графин хереса, из которого человека два выпили по рюмке, другие и не заметили его (Гончаров, с. 21).

В предыдущем фрагменте автор узнает значение сочетания авральная работа, а здесь ироническая тональность становится средством освоения нового знания (новой номинативной единицы). В контексте обнаруживается противопоставление ожиданий, связанных с пресуппозицией автора, и реальности. При этом свои ожидания автор соотносит и с ожиданиями читателя (судя по прежним слу$х а м)$. Представление об авральной работе за пуншем встает в один ряд с другими подобными ему представлениями о морских путешествиях людей, далеких от моря.

Контактоустанавливающую функцию ироническая тональность реализует и при описании курьезных ситуаций:

Мы вошли в лифт, и мальчик в красной куртке с золотыми пуговицами изящным движением нажал красивую кнопку. Новенький блестящий 
лифт немного поднялся вверх, застрял между этажами и неожиданно двинулся вниз, не обращая внимания на мальчика, который отчаянно нажимал кнопки (Ильф, Петров, с. 7).

В современном трэвел-медиатексте (термин Т. Ю. Редькиной, используемый для обозначения существующих в медиапространстве текстов о путешествиях [Редькина, 2011; 2017]) контактоустанавливающая функция часто выходит на первый план, прагматические установки текста смещаются от просвещения к развлечению:

А оказалось, что колодец снесли из-за какогото Моцарта, да еще и площадь в честь него переименовали. Было из-за чего негодовать. Сегодня памятник на площади Моцарта любим всеми. В Рождество ему на голову надевают шапочку Санта-Клауса. По-свойски, и далее: Зальцбург - город маленький. Но гордый (Моротская, с. 50).

Примечательно, что с изменением функции иронической тональности меняются и средства ее реализации: на первый план выходят языковая игра и трансформация прецедентных феноменов.

В ряде случаев ироническая тональность в травелоге используется с целью снятия категоричности оценки, что позволяет обеспечить гармонизацию дискурса. Так, во «Фрегате “Паллада"» при описании разговора с одним из японских чиновников (к нему автор испытывает явную симпатию) приводится диалог, в котором автор разворачивает перед своим собеседником гипотетическую перспективу путешествия его в Россию, на что японец отвечает резким отказом по причине отсутствия в России женщин:

- Так что же вам за дело до женщин? - спросил я. Он усмехнулся. Каков японский Дон Жуан! (Гончаров, с. 447).

В данном случае очевидно нежелание автора представить человека, о котором он говорит, в негативном свете. Ирония снимает отрицательную оценку.

\section{Эстетическая функция}

Авторская субъективность восприятия действительности в травелоге часто проявляется в стремлении к эстетизации иной дей- ствительности как объекта изображения. Для читателя важно не только получение сведений о другой действительности, но и знакомство с эстетической стороной странствия как вида деятельности. Ирония представляет собой одно из средств эстетизации. Например:

Спокойный океан скучен. 18 дней мы ползем, как муха по зеркалу. Хорошо поставленное зрелище было только один раз; уже на обратном пути из Нью-Йорка в Гавр. Сплошной ливень вспенил белый океан, белым заштриховал небо, сшил белыми нитками небо и воду. Потом была радуга. Радуга отразилась, замкнулась в океане, - и мы, как циркачи, бросались в радужный обруч. Потом - опять пловучие губки, летучие рыбки, летучие рыбки и опять пловучие губки Сарагоссова моря, а в редкие торжественные случаи - фонтаны китов. И все время надоедающая (даже до тошноты) вода и вода (Маяковский, с. 265).

Данный фрагмент является образцом наполненного красками описания пейзажа, надоевшего автору (самоирония). При этом ироническая тональность вносит в описание дополнительную экспрессивность, способствующую эстетизации реальности морского путешествия.

\section{Полифунциональность иронической тональности}

При характеристике отдельных функций иронической тональности в травелоге следует обратить внимание на то, что они не выступают обособленно. Это видно из контекстов, приводимых в качестве иллюстрации к каждой из функций. Просветительскую функцию иронии мы считаем основной потому, что она реализуется практически во всех иронических контекстах путешествий. Очевидно, что приведенный выше фрагмент из «Фрегата “Паллада"» И.А. Гончарова, содержащий описание сборов автора в путешествие по Сибири и перечисление приготовленных вещей, является примером реализации не только просветительской, но и других функций иронической тональности. Помимо собственно просветительской она выполняет следующие функции: контактоустанавливающую (интересный рассказ о типичной бытовой ситуации в форме диалога с читателем; использованы глаголы 2 л. ед. ч.), эстетическую, 


\section{МАТЕРИАЛЫ И СООБЩЕНИЯ}

побудительную, поскольку читатель приглашается если не попробовать сделать нечто подобное, то хотя бы мысленно «примерить» данную ситуацию на себя.

\section{Выводы}

Полифункциональность иронической тональности в травелоге свидетельствует о значимости данного явления в текстах такого типа. Продуктивность использования иронической тональности в травелоге обусловлена как коммуникативно-прагматическими характеристиками иронии, так и жанровыми особенностями самого травелога. С его бытованием как текста просветительского характера связана просветительская функция иронической тональности; ориентация на диалог с читателем, нацеленный на информирование и развлечение, определяет реализацию контактоустанавливающей функции, обеспечивающей бесконфликтность этого диалога; элемент художественности, присущий травелогу, детерминирует наличие у иронии эстетической функции.

Характер сочетания функций в каждом конкретном контексте зависит также от особенностей индивидуального стиля конкретного автора. Как отмечает Н.С. Болотнова, «К основным экстралингвистическим параметрам в анализе текста относятся: фактор адресата, личность автора, “стоящего" за текстом, социально-исторический и культурный контекст эпохи, значимый для диалога автора и читателя. Учет этих экстралингвистических параметров важен для смысловой интерпретации текста. Данная проблема связана со структурой кодов текста, к которым приобщается читатель в процессе интерпретационной деятельности» [Болотнова, 2006, с. 468].

Таким образом, продолжением исследования функционирования иронической тональности в травелоге может стать сравнение в этом аспекте текстов путешествий разных эпох и разных авторов.

\section{СПИСОК ЛИТЕРАТУРЫ}

Архипов И. К., 2007. Делу - время, потехе - час. О смешном и несмешном // Логический ана- лиз языка. Языковые механизмы комизма. М. : Индрик. С. 112-120.

Беккер И. Л., 2011. О социокультурных и психолого-педагогических аспектах пугешествия как способа бытия и познания мира // Известия Пензенского государственного педагогического университета им. В.Г. Белинского. № 24. C. $558-561$.

Болотнова Н. С., 2006. Филологический анализ текста. Томск : Изд-во Том. гос. пед. ун-та. $631 \mathrm{c}$.

Гомлешко Б. А., 2008. Прагматические функции иронии в тексте // Вестник Адыгейского государственного университета. Серия 2, Филология и искусствоведение. № 3. С. 11-13.

Дускаева Л. Р., 2014. Познавательно-просветительская медиаречь: репрезентация коммуникативного сценария трэвел-медиатекстов // Научные ведомости Белгородского университета. Серия: Гуманитарные науки : Филология. Журналистика. Педагогика. Психология. № 26 (197). Вып. 24. С. 85-92.

Ильинова Е. Ю., Цинкерман Т. Н., 2019. Прагматика коммуникативной тональности в стилистике англоязычного воспитывающего диалога // Вестник Волгоградского государственного университета. Серия 2, Языкознание. Т. 18, № 1. C. 146-158. DOI: 10.15688/jvolsu2.2019.1.12.

Карасик В. И., 2008. Коммуникативная тональность // Вестник Северо-Осетинского государственного университета им. К.Л. Хетагурова. № 2-4. C. 20-29.

Козлов С. А., 2003. Русский путешественник эпохи Просвещения. В 3 т. Т. 1. СПб. : Ист. ил. 496 с.

Кочетова Л. А., Плавина А. А., 2018. Дискурсивные стратегии репрезентации «иной» действительности в жанре травелога в культурно-историческом аспекте // Когнитивные исследования языка. № 34. С. 414-417.

Лосев А. Ф., 1966. Ирония античная и романтическая // Эстетика и искусство. М. : Искусство. C. 54-84.

Лотман Ю. М., Успенский Б. А., 1987. «Письма русского путешественника» Карамзина и их место в развитии русской культуры // Карамзин Н. М. Письма русского путешественника. Л. : Наука. C. 525-606.

Малышев А. А., 2015. Лингвостилистические особенности культурно-просветительских журналистских текстов первой половины XVIII века // Медиалингвистика. № 3 (9). С. 101-112. URL: https://medialing.ru/lingvostilisticheskieosobennosti-kulturno-prosvetitelskihzhurnalistskih-tekstov-pervoj-poloviny-xviiiveka/ (дата обращения: 01.07.2019).

Малышев А. А., 2016. Рациональный подход как основа познания мира в статьях «Примеча- 
ний к Санкт-Петербургским ведомостям» // Все истины мира: разум в литературе и искусстве. СПб. : Изд-во Марины Батасовой. C. $133-141$.

Матвеева Т. В., 2003. Тональность // Стилистический энциклопедический словарь русского языка / под ред. М. Н. Кожиной. М. : Флинта : Наука. С. 549-552.

Медиалингвистика в терминах и понятиях : слов.справ. / под ред. Л. Р. Дускаевой, 2018. М. : Флинта. 440 c.

Плавина А. А., 2019. Жанровые характеристики травелога в англоязычном дискурсе: динамический аспект // Филологические науки. Вопросы теории и практики. Т. 12, № 3. С. 72-78. DOI: 10.30853/filnauki.2019.3.15.

Пономарёв Е. Р., 2011. Типология советского путешествия. Советский путевой очерк 1920-1930-х годов. СПб. : СПГУТД. 275 с.

Редькина Т. Ю., 2011. Речевая разработка темы «другая страна» // Русская речь в средствах массовой информации. Речевые системы и речевые структуры. СПб. : Изд-во СПбГУ. C. $70-123$.

Редькина Т. Ю., 2017. От журналистики путешествий - к трэвел-медиатексту // История научно-популярной прессы России в социокультурном контексте. СПб. : Изд-во СПбГУ. C. 249-271.

Стефко М. С., 2009. Идея и практика «образовательного путешествия» (конец XVIII - начало XIX вв.) // Высшее образование в России. № 2. C. $145-150$.

Строганов М. В., 2002. Странствователь и домосед // Строганов М. В. Литературоведение как человековедение : Работы разных лет. Тверь : Золотая буква. С. 257-274.

Трач А. С., 2007. Экономия и избыточность сегментных средств в комическом тексте (на материале произведений М.М. Жванецкого) // Логический анализ языка. Языковые механизмы комизма. М. : Индрик. С. 175-185.

Тупикова С. Е., 2011. Категория тональности и уровни ее репрезентации в жанре светской хроники // Вопросы когнитивной лингвистики. Вып. 4. С. 68-73.

Тупикова С. Е., 2017. Когнитивные модели некоторых видов тональности англо- и франкоязычного медиадискурса // Известия Саратовского университета. Серия: Филология. Журналистика. Т. 17, вып. 4. С. 404- 407.

Шадрина М. Г., 2003. Эволюция языка «путешествий» : автореф. дис. ... д-ра филол. наук. М., $65 \mathrm{c}$.

Шачкова В. А., 2008. Путешествие как жанр художественной литературы: вопросы теории
// Вестник Нижегородского университета им. Н.И. Лобачевского. № 3. С. 277-281.

Щеглова Е. А., 2013. Особенности употребления фитонимов в очерках путешествия «Фрегат "Паллада"» И.А. Гончарова // Acta Linguistica Petropolitana. Труды института лингвистических исследований. Т. 9, № 2. С. 582-293.

Шёнле А., 2004. Подлинность и вымысел в авторском самосознании русской литературы путешествий. 1790-1840. М. : Акад. проект. 271 с.

Blanton C., 1997. Travel Writing. The Self and the World. N. Y. : Peter Lang. 148 p.

Chandler D., 2007. Semiotics: the Basics. L. ; N. Y. : Routledge. 307 p. DOI: 10.4324/9780203014936.

Leed E. J., 1978. The Mind of the Traveler. From Gilgamesh to Global Tourism. N. Y. : Pantheon Books. 328 p.

\section{ИСТОЧНИКИ}

Гончаров - Гончаров И. А. Фрегат «Паллада». Полное собрание сочинений и писем. В 20 т. Т. 2. СПб. : Наука, 1997. 745 с.

Вышеславцев - Вышеславцев А. В. Очерки пером и карандашом из кругосветного плавания в 1857, 1858, 1859 и 1860 годах. СПб. ; М. : Изд. М. О. Вольфа, 1867. 624 с.

Есенин-Есенин С. А. Железный Миргород (очерки об Америке) // Полное собрание сочинений. В 7 т. Т. 5. М. : Голос ; Наука, 1997. С. 161-172.

Ильф, Петров - Ильф И., Петров Е. Одноэтажная Америка // Собрание сочинений. В 5 т. Т. 4. М. : Гос. изд-во худож. лит., 1961. С. 7-450.

Маяковский - Маяковский В. В. Мое открытие Америки // Полное собрание сочинений. В 13 т. Т. 7. М. : Худож. лит., 1958. С. 265-346.

Михайлов-Михайлов М. Л., Лондонские заметки // Собрание сочинений. В 3 т. Т. 2. М. : Худож. лит., 1958. С. 306-368.

Моротская - Моротская С. Реквием с конями // Вокруг света. № 5. 2017. С. 48-55.

Успенский - Успенский Г. И. «Пока что» // Полное собрание сочинений. В 14 т. Т.10. Ч. 2. М. : Гос. изд-во худож. лит., 1955. С. 107-125.

\section{REFERENCES}

Arkhipov I.K., 2007. Delu - vremya, potekhe - chas. O smeshnom i nesmeshnom [To business - time, a fun - hour. About ridiculous and unhumorous]. Logicheskiy analiz yazyka. Yazykovye mekhanizmy komizma [Logical analysis of language. Language mechanisms of comedy]. Moscow, Indik Publ., pp. 112-120. 
Bekker I.L., 2011. O sociokulturnykh i psikhologopedagogicheskikh aspektakh puteshestviya kak sposoba bytiya i poznaniya mira [On sociocultural and psycho-pedagogical aspects of travelling as means of existence and cognition of the world]. Izvestiya Penzenskogo gosudarstvennogo pedagogicheskogo universiteta im. V.G. Belinskogo, no 24, pp. 558-561.

Bolotnova N.S., 2008. Filologicheskiy analiz teksta [Philological analysis of text]. Tomsk, Tomsk St. Pedag. Un. Publ. 631 p.

Gomleshko B.A., 2008. Pragmaticheskie funktsii ironii $v$ tekste [Pragmatical functions of irony in the text]. Vestnik Adygeyskogo gosudarstvennogo universiteta. Seriya 2: Filologiya $i$ iskusstvovedenie [Bulletin of the Adyghe State University. Philology and art Art History], no 3, pp. 11-13.

Duskaeva L.R., 2014. Poznavatelno-prosvetitelskaya mediarech: reprezentatsiya kommunikativnogo stsenariya trevel-mediatekstov [Educational media speech: representation of the communicative script of travel media texts]. Nauchnye vedomosti Belgorodskogo universiteta. Seriya Gumanitarnye nauki: Filologiya. Zhurnalistika. Pedagogika. Psikhologiya [Belgorod State University Scientific bulletin. Philology. Journalism. Pedagogy. Psychology], no 26 (197), pp. 85-92.

Ilyinova E.Yu., Tsinkerman T.N., 2019. Pragmatika kommunikativnoj tonalnosti $\mathrm{v}$ stilistike angloyazychnogo vospityvayushchego dialoga [Pragmatics of communicative tonality in the stylistics of English educative converse]. Vestnik Volgogradskogo gosudarstvennogo universiteta. Seriya 2: Yazykoznanie [Science Journal of Volgograd State University. Linguistics], vol. 18, no 1,pp. 146-158. DOI: 10.15688/jvolsu2.2019.1.12.

Karasik V.I., 2008. Kommunikativnaya tonalnost [Communicative key]. Vestnik SeveroOsetinskogo gosudarstvennogo universiteta im. K.L. Hetagurova [Bulletin of the North Ossetian State University named after K.L. Khetagurov], no 2-4, pp. 20-29.

Kozlov S.A., 2003. Russkiy puteshestvennik epokhi Prosveshcheniya. V3t. T. 1 [Russian traveler of the age of Enlightenment. In 3 vols. Vol. 1]. Saint Petersburg, Istoricheskaya illyustraciya Publ. 496 p.

Kochetova L.A., Plavina A.A., 2018. Diskursivnye strategii reprezentatsii «inoy» deystvitelnosti v zhanre traveloga v kulturno-istoricheskom aspekte [Discursive strategies of 'other' culture representation in the genre of travelogue in cultural and historical perspective]. Kognitivnye issledovaniya yazyka [Cognitive studies of language], no 34, pp. 414-417.
Losev A.F., 1966. Ironiya antichnaya i romanticheskaya [Irony antique and romantic]. Estetika $i$ iskusstvo [Aesthetics and art]. Moscow, Iskusstvo Publ., pp. 54-84.

Lotman Yu.M., Uspenskiy B.A., 1987. "Pisma russkogo puteshestvennika" Karamzina i ikh mesto v razvitii russkoy kultury ["Letters of the Russian traveler" by Karamzin and their place in development of the Russian culture]. Karamzin N.M. Pisma russkogo puteshestvennika [Letters of the Russian traveler]. Leningrad, Nauka Publ., pp. 525-606.

Malyshev A.A., 2015. Lingvostilisticheskie osobennosti kulturno-prosvetitelskkih zhurnalistskikh tekstov pervoy poloviny XVIII veka [Linguistic and stylistic features of the cultural and educational journalistic texts of the first half of the XVIII century]. Medialingvistika [Media Linguistics], no. 3 (9), pp. 101-112. Available at: https:// medialing.ru/lingvostilisticheskie-osobennostikulturno-prosvetitelskih-zhurnalistskih-tekstovpervoj-poloviny-xviii-veka/ (accessed: 01.07.2019).

Malyshev A.A., 2016. Racionalnyy podkhod kak osnova poznaniya mira v statyakh «Primechaniy k Sankt-Peterburgskim vedomostyam» [Rational approach as a basis of knowledge of the world in articles of "Notes to the St. Petersburg sheets"]. $V$ se istiny mira: razum $v$ literature $i$ iskusstve [All truth of the world: reason in literature and art]. Saint Petersburg, Marina Batasova's publishing house, pp. 133-141.

Matveeva T.V., 2003. Tonalnost [Tonality]. Stilisticheskiy enciklopedicheskiy slovar russkogo yazyka [Stylistic Encyclopedic Dictionary of the Russian Language]. Moscow, Flinta Publ., Nauka Publ., pp. 549-552.

Medialingvistika..., 2018. Medialingvistika v terminakh i ponyatiyakh. Slovar-spravochnik [Media linguistics in terms and concepts. Dictionary reference]. L.R. Duskaeva (ed.). Moscow, Flinta Publ. 440 p.

Plavina A.A., 2019. Zhanrovye harakteristiki traveloga v angloyazychnom diskurse: dinamicheskiy aspekt [Travelogue genre characteristics in the English discourse: dynamic aspect]. Filologicheskie nauki. Voprosy teorii i praktiki [Philology. Theory \& Practice], vol. 12, no. 3, pp. 72-78.

Ponomarev E.R., 2011. Tipologiya sovetskogo puteshestviya. Sovetskiy putevoy ocherk $19201930 k h$ godov [Typology of the Soviet travel. Soviet traveling sketch 19201930 years]. Saint Petersburg, Saint Petersburg State University of Telecommunications Publ., 275 p.

Redkina T.Yu., 2011. Rechevaya razrabotka temy "drugaya strana" [Speech development of the 
subject "other country"]. Russkaya rech $v$ sredstvakh massovoy informatsii. Rechevye sistemy i rechevye struktury [Russian speech in mass media. Speech systems and speech structures]. Saint Petersburg, Saint Petersburg State University Publ., pp. 70123.

Redkina T.Yu., 2017. Ot zhurnalistiki puteshestviy $-\mathrm{k}$ trevel-mediatekstu [From travel journalism - to travel media]. Istoriya nauchno-populyarnoy pressy Rossii v sociokulturnom kontekste [History of the scientific and popular press of Russia in a sociocultural context]. Saint Petersburg, Saint Petersburg State University Publ., pp. 249-271.

Stefko M.S., 2009. Ideya i praktika «obrazovatelnogo puteshestviya» (konec XVIII - nachalo XIX vv.) [The idea and practice of "educational travel")]. Vysshee obrazovanie $v$ Rossii [Higher education in Russia], no 2, pp. 145-150.

Stroganov M.V., 2002. Stranstvovatel i domosed [Traveller and homebody]. Stroganov M. V. Literaturovedenie kak chelovekovedenie: Raboty raznykh let [Literary criticism as anthropology: Works of different years]. Tver, Zolotaya bukva Publ., pp. 257-274.

Trach A.S., 2007. Ekonomiya i izbytochnost segmentnykh sredstv v komicheskom tekste (na materiale proizvedeniy M.M. Zhvanetskogo) [Economy and redundancy of segment means in the comic text (on material of works by M. M. Zhvanetsky)]. Logicheskiy analiz yazyka. Yazykovye mekhanizmy komizma [Logical analysis of language. Language mechanisms of comedy]. Moscow, Indik Publ., pp. 175-185.

Tupikova S.E., 2011. Kategoriya tonalnosti i urovni ee reprezentacii $\mathrm{v}$ zhanre svetskoy khroniki [The category of tonality and its levels of representation in society colum genre]. Voprosy kognitivnoy lingvistiki [Issues of cognitive linguistics], no. 4, pp. 68-73.

Tupikova S.E., 2017. Kognitivnye modeli nekotorykh vidov tonalnosti anglo- $\mathrm{i}$ frankoyazychnogo mediadiskursa [Cognitive models of some tonality types of English and French media discourse]. Izvestiya Saratovskogo universiteta. Seriya Filologiya, Zhurnalistika [Izvestiya of Saratov University. New Series. Series: Philology, Journalism], vol. 17, no 4, pp. 404-407.

Shadrina M.G., 2003. Evolyutsiya yazyka "puteshestviy": diss. ... dokt. filol. nauk [Evolution of language of travelogue: : Dokt. philol. sci. abs.diss.]. Moscow. 65 p.

Shachkova V.A., 2008. Puteshestvie kak zhanr khudozhestvennoy literatury: voprosy teorii
[Travelogue as a genre of fiction: theoretical issues]. Vestnik Nizhegorodskogo universiteta im. N.I. Lobachevskogo [Vestnik of Lobachevsky University of Nizhny Novgorod], no 3, pp. 277-281.

Shcheglova E.A., 2013. Osobennosti upotrebleniya fitonimov v ocherkakh puteshestviya «Fregat "Pallada"» I.A. Goncharova [Specific uses of phytonyms in I. Goncharov's Frigate "Pallada" voyage sketches]. Acta Linguistica Petropolitana. Trudy instituta lingvisticheskikh issledovaniy [Acta Linguistica Petopolitana. Transactions of the institute for linguistic studies], vol. 9, no 2, pp. 582-293.

Schönle A., 2004. Podlinnost $i$ vymysel v avtorskom samosoznanii russkoy literatury puteshestviy. 1790-1840 [Authenticity and fiction in author's consciousness of the Russian literature of travel. 1790-1840]. Moscow, Akademicheskiy proekt Publ., 271 p.

Blanton C., 1997. Travel Writing. The Self and the World. New York, Peter Lang. 148 p.

Chandler D., 2007. Semiotics: the Basics. London; New York, Routledge. 307 p. DOI: 10.4324/ 9780203014936.

Leed E.J., 1978. The Mind of the Traveler. From Gilgamesh to Global Tourism. New York, Pantheon Books. 328 p.

\section{SOURCES}

Goncharov I.A. Fregat «Pallada» [The Frigate "Pallada"]. Polnoe sobranie sochineniy i pisem. $V 20 t$. [Complete works and letters. In 20 vol.]. Vol. 2. Saint Petersburg, Nauka Publ., 1997. 745 p.

Vysheslavtsev A.V. Ocherki perom i karandashom iz krugosvetnogo plavaniya v 1857, 1858, 1859 i 1860 godakh [Sketches a feather and a pencil from a global cruise in 1857, 1858, 1859 and 1860]. Saint Petersburg, Moscow, Izdanie M.O. Volfa, $1867.624 \mathrm{p}$.

Esenin S.A. Zheleznyy Mirgorod (ocherki ob Amerike) [Iron Mirgorod (essays on America)]. Polnoe sobranie sochineniy. $V 7 t$. [Complete works. In 7 vol.]. Vol. 5. Moscow, Golos; Nauka Publ., 1997., pp. 161-172.

Ilf I., Petrov E. Odnoetazhnaya Amerika [One-story America]. Sobranie sochineniy $v 5 t$. [Collected works.In 5 vol.]. Moscow, Hudozhestvennaya literature Publ., 1961, pp. 7-450.

Mayakovskiy V.V. Moe otkrytie Ameriki [My discovery of America]. Polnoe sobranie sochineniy. $V 13 \mathrm{t}$. [Complete works. In 13 vol.]. Vol. 7. Moscow, Hudozhestvennaya literature Publ., 1958, pp. 265-346.

Mikhaylov M.L. Londonskie zametki [London Notes]. Sobranie sochineniy. V $3 t$. [Collected works. 


\section{МАТЕРИАЛЫ И СООБЩЕНИЯ}

In 3 vol.]. Vol. 2. Moscow, Hudozhestvennaya literatura Publ., 1958, pp. 306-368.

Morotskaya S. Rekviem s konyami [Requiem with horses]. Vokrug sveta [Around the world], no 5, 2017, pp. 48-55.
Uspenskiy G. I. Iz putevykh zametok [From the travel notes]. Polnoe sobranie sochineniy $v 14 t$. [Complete works. In 14 vol.]. Vol. 10, part 2. Moscow, Hudozhestvennaya literature Publ., 1958,pp. 107-125.

\section{Information About the Author}

Ekaterina A. Shcheglova, Candidate of Sciences (Philology), Associate Professor, Media Linguistics Department, Saint Petersburg State University, 1-ya Liniya Vasilyevskogo Ostrova, 26, 199004 Saint Petersburg, Russia, e.scheglova@spbu.ru, e.shcheglova@bk.ru, https://orcid.org/0000-0003-1778-2021

\section{Информация об авторе}

Екатерина Александровна Щеглова, кандидат филологических наук, доцент кафедры медиалингвистики, Санкт-Петербургский государственный университет, 1-я линия Васильевского Острова, 26, 199004 г. Санкт-Петербург, Россия, e.scheglova@spbu.ru, e.shcheglova@bk.ru, https://orcid.org/0000-0003-1778-2021 